\title{
Post-extubation Oxygenation Strategies and Mortality and Reintubation Rates in Acute Respiratory Failure: A Systematic Review and Network Meta-Analysis
}

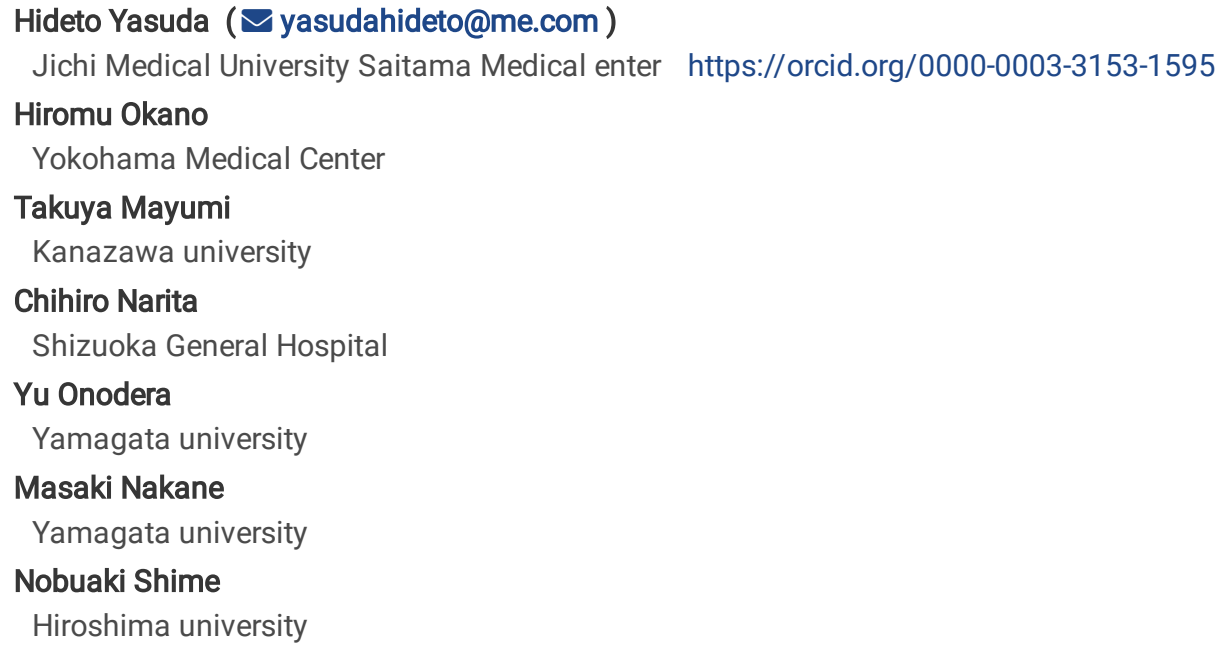

\section{Research}

Keywords: post-extubation, conventional oxygen therapy, noninvasive ventilation, high-flow nasal cannula, systematic review, meta-analysis, network meta-analysis

Posted Date: March 1st, 2021

DOI: https://doi.org/10.21203/rs.3.rs-270103/v1

License: (c) This work is licensed under a Creative Commons Attribution 4.0 International License. Read Full License

Version of Record: A version of this preprint was published at Critical Care on April 9th, 2021. See the published version at https://doi.org/10.1186/s13054-021-03550-4. 


\section{Abstract}

Background: High-flow nasal cannula oxygenation (HFNC) and noninvasive positive-pressure ventilation (NPPV) possibly decrease tracheal reintubation rates better than conventional oxygen therapy (COT); however, few large-scale studies have compared HFNC and NPPV. We conducted a network meta-analysis (NMA) to compare the effectiveness of three post-extubation respiratory support devices (HFNC, NPPV, COT) in reducing the mortality and reintubation risk.

Methods: The Cochrane Central Register of Controlled Trials, MEDLINE, EMBASE, and Ichushi databases were searched. COT, NPPV, and HFNC use were assessed in patients aged $\geq 16$ years who underwent invasive mechanical ventilation for $>12$ hours for acute respiratory failure and were scheduled for extubation after spontaneous breathing trials. The GRADE Working Group Approach was performed using a frequentistbased approach with multivariate random-effects meta-analysis. Short-term mortality and reintubation and post-extubation respiratory failure rates were compared.

Results: After evaluating 4,631 records, 15 studies and 2,600 patients were included. The main cause of acute hypoxic respiratory failure was pneumonia. Although NPPV/HFNC use did not significantly lower the mortality risk (relative risk [95\% confidence interval], 0.75 [0.53-1.06] and 0.92 [0.67-1.27]; low and moderate certainty, respectively), HFNC use significantly lowered the reintubation risk (0.54 [0.32-0.89]; high certainty) compared with COT use. The associations of mortality with NPPV and HFNC in either outcome did not differ significantly (short-term mortality and reintubation, relative risk [95\% confidence interval], 0.81 [0.61-1.08] and 1.02 [0.53-1.97]; moderate and very low certainty, respectively).

Conclusion: NPPV or HFNC use may reduce endotracheal reintubation risk, but not short-term mortality risk.

\section{Trial registration number and date of registration}

PROSPERO (registration number: CRD42020139112, 01/21/2020).

\section{Background}

Invasive mechanical ventilation (IMV) is a life-saving procedure for patients with acute respiratory failure (ARF)[1]. Approximately 10-20\% of patients who are extubated after a successful spontaneous breathing trial (SBT) require reintubation within 48-72 hours[2], which may be associated with prolonged mechanical ventilation, extended intensive care unit (ICU) and hospital stay, and increased mortality[2, 3].

Various oxygenation therapies have been proposed to prevent reintubation in ARF due to several causes, including hypoxia, ventilatory insufficiency, and increased respiratory workload. Conventional oxygen therapy (COT) and noninvasive positive-pressure ventilation (NPPV) have been recommended as post-extubation respiratory support devices[4-7]; recently, high-flow nasal cannula oxygenation (HFNC) has also been used as a prophylactic post-extubation respiratory support device to avoid reintubation[8, 9].

NPPV has been reported to be effective in preventing reintubation after planned extubation in high-risk patients[6, 7, 10, 11]. However, NPPV may increase the risk of complications, including aspiration pneumonia, interface intolerance, and patient discomfort[12, 13]. HFNC can minimize the complications of NPPV by delivering high concentrations of humidified oxygen via a nasal cannula. However, contradictory results have been reported despite the large number of clinical trials[14, 15].

Some systematic reviews and meta-analyses which compared two of the three respiratory support devices (COT, NPPV, and HFNC)[16-20] have shown that in terms of reducing the rate of tracheal reintubation, HFNC was better than COT but equivalent to NPPV. Moreover, there were no significant differences between the therapies in terms of mortality rates. Although several studies have compared HFNC with COT and NPPV with COT, few large-scale studies have compared HFNC with NPPV. Therefore, small sample sizes may have affected the results of systematic reviews.

To overcome these limitations, we performed a systematic review and network meta-analysis (NMA) to compare the effectiveness of three respiratory support devices in reducing mortality and reintubation rates by including studies that compared two of the three respiratory support devices (COT, NPPV, and HFNC) in patients with ARF.

\section{Methods}

\section{Protocol and registration}

This systematic review was designed in accordance with the Preferred Reporting Items for Systematic review and Meta-Analyses (PRISMA) extension statements for reporting systematic reviews that incorporate NMA (e-Table 1 in additional file 1)[21]. The review protocol is registered with PROSPERO (CRD42020139112). 
We included all reports of randomized controlled trials (RCTs) in English and Japanese regardless of publication status (e.g., published, unpublished, and academic abstracts). Randomized crossover, cluster randomized, and quasi-experiment trials were excluded. This metaanalysis included reviews of adult patients (age $\geq 16$ years) who underwent IMV for more than 12 hours due to ARF and were scheduled for extubation after an SBT. The definitions of acute hypoxic respiratory failure and SBT were individualized for each study. This meta-analysis excluded studies that included patients who underwent tracheostomies, experienced accidental extubation or self-extubation, those who experienced hypercapnia during SBT, and those who had do-not-resuscitate (DNR) orders. Studies in which more than half of the study population had acute chronic obstructive pulmonary disease (COPD) exacerbation, those that included patients with a postoperative status or who were being treated for trauma, and those that included patients with congestive heart failure were also excluded. We included RCTs that compared two of the three available respiratory support devices: (1) COT: low-flow nasal cannula, face mask, and venturi mask (no flow rate restriction); (2) NPPV: the type of mask, mode, duration of ventilation, and weaning methods were not limited; and (3) HFNC: no limitations on the flow rate or $\mathrm{F}_{1} \mathrm{O}_{2}$. The outcome measures evaluated were as follows: the primary outcome was the short-term mortality rate ([1] at the end of the follow-up period for each trial within 30 days, [2] at ICU discharge, and [3] at hospital discharge). Secondary outcomes included the reintubation rate within 72 hours (reintubation included the need for intubation and NPPV) and post-extubation respiratory failure rate (the definition was individualised for each study).

\section{Data sources and search details}

We searched the Cochrane Central Register of Controlled Trials (CENTRAL), MEDLINE via PubMed, EMBASE, and Ichushi, a database of Japanese papers for eligible trials. We searched for ongoing trials in the World Health Organization International Clinical Trials Platform Search Portal. In cases of missing data, we attempted to contact the authors of each study. Searches were performed in December 2020. Details regarding search strategy and when the searches were performed are shown in e-Table 2 in additional file 1.

\section{Study selection, data collection process, and data items}

Two of the three physicians (YO, CN, and HY) screened the title, abstract, and full text during the first and second screenings for relevant studies and independently extracted data from eligible studies into standardized data forms. For abstract-only studies that could not be evaluated according to the eligibility criteria, we contacted the authors. Disagreements, if any, between two reviewers were resolved via discussion among themselves or with a third reviewer as necessary. Data extraction from identified studies during the second screening was done by three reviewers using two tools: (1) the Cochrane Data Collection Form (RCTs only)[22] and (2) Review Manager (RevMan) software V.5.3.5[23].

\section{Risk of bias within individual studies}

The risk of bias for primary outcomes were independently assessed using the Cochrane Risk of Bias tool 1.0[24, 25]. Each bias was graded as 'low risk', 'unclear risk', or 'high-risk'. Discrepancies between reviewers were resolved by mutual discussion.

\section{Statistical analyses}

\section{Direct comparison meta-analysis}

A pairwise meta-analysis was performed by using RevMan 5.3 (RevMan 2014). Forest plots were used for the meta-analysis, and effect sizes are expressed as relative risk (RR) and weighted mean differences, both with $95 \%$ confidence intervals (Cl), for categorical and continuous data, respectively. Outcome measures were pooled using a random effect model to include study-specific effects in measures. A two-sided $p$-value $<0.05$ was considered significant.

Study heterogeneity between trials for each outcome was assessed by visual inspection of forest plots and with an $\mathrm{I}^{2}$ statistic for quantifying inconsistency [26] (RevMan; $\mathrm{I}^{2}$ : 0-40\%, 30-60\%, 50-90\%, and 75-100\% as minimal, moderate, substantial, and considerable heterogeneity, respectively). When heterogeneity was identified $\left(I^{2}>50 \%\right)$, we investigated the reason and quantified it using the Chi-square test ( $p$-value).

We planned to use a funnel plot, Begg's adjusted rank correlation test, and Egger's regression asymmetry test for the possibility of publication bias if $\geq 10$ studies were available (RevMan) [27]. However, as $<10$ studies were included for each outcome, we did not test for funnel plot asymmetry.

\section{Network comparison meta-analysis}

Data synthesis

A network plot was constructed to determine the number of studies and patients included in this meta-analysis. An NMA, using the netmeta 0.95 R-package (version 3.5.1), was performed using a frequentist-based approach with multivariate random effects meta-analysis, and effect size 
was expressed as the RR $(95 \% \mathrm{Cl})$. Covariance between two estimates from the same study shows variance of data in the shared arm, as calculated in a multivariable meta-analysis performed using the GRADE Working Group Approach for an NMA.

\section{Transitivity}

The transitivity assumption underlying the NMA was evaluated by comparing the distribution of clinical and methodological variables that could act as effect modifiers across treatment comparisons.

\section{Ranking}

Ranking plots (rankograms) were constructed using the probability that a given treatment had the highest event rate for each outcome. The surface under the cumulative ranking curve (SUCRA), which is a simple transformation of the mean rank, was used to set the hierarchy of the treatments[28] and was created using standard software (Stata 15.0, Stata, TX, USA).

\section{Risk of bias across studies}

Assessment of the risk of bias across studies followed considerations on pairwise meta-analysis. Conditions associated with 'suspected' and 'undetected' bias across studies were determined by the presence of publication bias as shown by direct comparison.

\section{Indirectness}

The indirectness of each study included in the network was evaluated according to its relevance to the research question, which consisted of the study population, interventions, outcomes, and study setting, and was classified as low, moderate, or high. Study-level judgments could be combined with the percentage contribution matrix.

Imprecision

The approach to imprecision comprised a comparison of the range of treatment effects included in the $95 \% \mathrm{Cl}$ with the range of equivalence. We assessed the heterogeneity of treatment effects for a clinically important risk ratio $(<0.8$ or $>1.25)$ in $\mathrm{Cl}$.

Heterogeneity

To assess the amount of heterogeneity, we compared the posterior distribution of the estimated heterogeneity variance with its predictive distribution[29]. The concordance between assessments based on $\mathrm{Cl}$ and prediction intervals, which do and do not capture heterogeneity, respectively, was used to assess the importance of heterogeneity. We assessed the heterogeneity of treatment effects for a clinically important risk ratio of $<0.8$ or $>1.25$ in prediction intervals.

\section{Assessment of inconsistency}

The inconsistency of the network model was estimated from inconsistency factors and their uncertainty, and consistency was statistically evaluated using the design-by-treatment interaction test[30]. For comparisons informed only by direct evidence, there was no disagreement between evidence sources and, thus, there was 'no concern' for incoherence. If only indirect evidence was included, there was always 'some concern'. 'Major concern' applied when the $p$-value of the design-by-treatment interaction test was $<0.01$.

\section{Results}

\section{Study selection}

A comprehensive search yielded a total of 4,631 records (e-Fig 1 in additional file 1) from which 15 studies were included in this NMA [6, 14, 15, 31-42]. Of the 15 studies, one [35] was an abstract that was presented at a conference and not published elsewhere. None of the studies was a three-group study that directly compared NPPV with HFNC and COT; 5, 9, and 1 study compared NPPV with COT, HFNC with COT, and HFNC with NPPV, respectively (network structures per outcome in Fig 1).

\section{Study characteristics}

The protocols and characteristics of each study included in this meta-analysis are summarized in Table 1. A total of 2,600 patients were included in the quantitative analysis. The main cause of acute hypoxic respiratory failure was pneumonia, followed by postoperative respiratory failure. Of the 15 studies, two mainly included patients with exacerbation of chronic respiratory disorders.

\section{$\underline{\text { Risk of bias within studies }}$}


The risk of bias within included studies is shown in e-Fig 2 in additional file 1. Although not all studies blinded participants and clinicians to the intervention, almost all other domains of the risk of bias were low (e-Fig 2 in additional file 1). All studies were judged as having a low risk of bias for outcomes (risk of bias across studies).

\section{Network meta-analysis}

The results of pairwise comparisons are shown in e-Figs 3, 4, and 5 in additional file 1 (short-term mortality, reintubation, and post-extubation respiratory failure, respectively). The funnel plot of each outcome was not described because the number of studies included for each comparison was $<10$.

\section{Short-term mortality}

Thirteen studies were included in the analysis of short-term mortality. Compared with COT, NPPV (RR, 0.75 [95\% Cl, 0.53-1.06]: low certainty) and HFNC (RR, 0.92 [95\% Cl, 0.67-1.27]: moderate certainty) were not associated with a lower risk of mortality (Fig 2a). There was no significant difference in the association with mortality between NPPV and HFNC (RR, 0.81 [95\% Cl, 0.61-1.08]: moderate certainty). Anticipated absolute effects and $95 \%$ Cls between two comparisons decreased by 26 per $1,000(95 \% \mathrm{Cl},-49$ to +6$)$ for NPPV vs. COT, 7 per 1,000 ( $95 \% \mathrm{Cl},-28$ to +23$)$ for HFNC vs. COT, and 39 per $1,000(95 \% \mathrm{Cl},-79$ to +16$)$ for NPPV vs. HFNC (Table 2$)$.

Confidence in the RR of each comparison and short-term mortality, assessed by the GRADE system, is shown in Table 3. Incoherence between direct and indirect RRs was not observed for any of the three comparisons, according to the $p$-values of inconsistency. The heterogeneity for all three comparisons resulted in a 'no concern' rating due to the $95 \%$ prediction interval of the risk ratio.

Fig 3a shows the ranking analysis results, which revealed that the hierarchy for efficacy in reducing short-term mortality was NPPV (SUCRA 93.2) > HFNC (SUCRA 36.7) > COT (SUCRA 20.1). Table 2 summarizes the findings of the NMA for short-term mortality. Moreover, e-Table 3 in additional file 1 summarizes the estimate and certainty of the evidence of direct, indirect, and network comparisons.

\section{Endotracheal reintubation}

Fourteen studies were included in the analysis of endotracheal reintubation. Compared with COT, HFNC (RR, 0.54 [95\% Cl, 0.32-0.89]: high certainty) was significantly associated with a lower risk of reintubation (Fig 2b), although there were no significant difference in the association with reintubation between NPPV and HFNC (RR, 1.02 [95\% Cl, 0.53-1.97]: low certainty), and between NPPV and COT (RR, 0.55 [95\% Cl, $0.30-$ 1.00]: moderate certainty). Anticipated absolute effects and $95 \% \mathrm{Cls}$ between each of the two comparisons decreased by 62 per 1,000 ( $95 \% \mathrm{Cl}$, -96 to 0$)$ for NPPV vs. COT and 60 per $1,000(95 \% \mathrm{Cl},-88$ to -14$)$ for HFNC vs. COT, but increased by 5 per $1,000(95 \% \mathrm{Cl},-107$ to +221$)$ for NPPV vs. HFNC (Table 4).

Table 3 shows the confidence in the RR of each comparison and reintubation assessed by the GRADE system. Incoherence between direct and indirect RRs was not observed for all three comparisons and was decided by the $p$-value of inconsistency. The heterogeneity of two comparisons (NPPV vs. COT and HFNC vs. COT) resulted in 'some concern' and 'major concern', but that of one comparison (HFNC vs. NPPV) resulted in a 'no concern' rating due to the $95 \%$ prediction interval of the risk ratio.

Fig 3b indicates the ranking analysis of the hierarchy for efficacy in reducing reintubation: HFNC (SUCRA 75.8) > NPPV (SUCRA 71.6) > COT (SUCRA 2.5). Table 4 summarizes findings of the NMA for reintubation; e-Table 3 in additional file 1 presents the estimate and certainty of the evidence of direct, indirect, and network comparisons.

\section{Post-extubation respiratory failure}

Seven studies were included in the analysis of post-extubation respiratory failure. Compared with COT, NPPV (RR, 0.86 [95\% Cl, 0.54-1.38]: Iow certainty) and HFNC (RR, 0.66 [95\% Cl, 0.43-1.02]: moderate certainty) were not associated with a lower risk of mortality (Fig 2c). There was no significant difference in the association with mortality between NPPV and HFNC (RR, 1.30 [95\% $\mathrm{Cl}, 0.79-2.14]$ : low certainty). Anticipated absolute effects and $95 \% \mathrm{Cls}$ between each of two comparison decreased by 26 per $1,000(95 \% \mathrm{Cl},-87$ to +71$)$ for NPPV vs. COT and 57 per $1,000(95 \% \mathrm{Cl},-95$ to +3$)$ for HFNC vs. COT, but increased by 81 per $1,000(95 \% \mathrm{Cl},-56$ to +307$)$ for NPPV vs. HFNC (Table 5$)$.

Table 3 shows the confidence in the RR of each comparison and post-extubation respiratory failure assessed by the GRADE system. Incoherence between direct and indirect RRs was not observed for all three comparisons, as indicated by the $p$-value of inconsistency. The heterogeneity of one comparison (HFNC vs. COT) and that of two comparisons (NPPV vs. COT and HFNC vs. NPPV) resulted in 'some concern' and 'no concern' ratings due to the $95 \%$ prediction interval of the risk ratio.

Fig 3c shows the results of the ranking analysis of the hierarchy for efficacy in reducing post-extubation respiratory failure: HFNC (SUCRA 93.5) > NPPV (SUCRA 43.2) > COT (SUCRA 13.3). Table 5 summarizes findings of the NMA for post-extubation respiratory failure, and e-Table 3 in 
additional file 1 summarizes the estimate and certainty of the evidence of direct, indirect, and network comparisons.

\section{Discussion}

In our NMA, there was no between-group differences in short-term mortality (groups: NPPV, HFNC, and COT). NPPV/HFNC use did not significantly lower the mortality risk. However, the use of HFNC significantly lowered the reintubation risk relative to the COT use. There were no significant differences in the rate of endotracheal reintubation or post-extubation respiratory failure between HFNC and NPPV. The mortality rate did not reduce in any two of the three comparisons.

Herein, NPPV contributed to a reduction in the reintubation rate compared to that observed with COT, without reducing mortality, which is consistent with several previous pairwise systematic reviews comparing NPPV and COT. Previous RCTs show that NPPV is more effective in reducing reintubation and mortality rates than $\mathrm{COT}$ in a high-risk group of patients with post-extubation respiratory failure, including COPD[7] [43-44]. However, Kondo et al. showed that NPPV decreased reintubation and mortality rates more effectively than COT despite the complete exclusion of COPD patients from the study [45]. In our study, we excluded studies with COPD patients constituting $>50 \%$ of the study population, as COPD is a risk factor for post-extubation respiratory failure [46]. Thus, the abovementioned exclusion potentially caused a difference between the effectiveness of NPPV and COT in the systematic reviews included in the NMA.

When HFNC was compared to COT, differences in outcomes between previous pairwise systematic reviews and this NMA-based study were observed. A systematic review by Ni and colleagues showed that HFNC is associated with a lower reintubation rate than COT, despite no reduction in mortality rate[16], which is identical to our study. Although a systematic review by Zhu et al. revealed that HFNC contributed to a reduction in post-extubation respiratory failure compared to that observed with COT, reductions in reintubation and mortality rates were not apparent [17]. In the study by Zhu et al. and our NMA, the effect of HFNC differed in terms of the reintubation rate; however, this difference is likely attributable to the eligibility of included patients. We excluded RCTs that included $>50 \%$ of postoperative patients, whereas the study by Zhu et al. included all RCTs with postoperative patients (three RCTs; $n=715$ ) [47]. In postoperative abdominal surgery patients, diaphragmatic dysfunction and decreased lung vital capacity can cause atelectasis, resulting in hypoxemic respiratory failure [48]. Including patients with such different mechanisms of respiratory failure may increase patient heterogeneity and result in different outcomes compared to those observed with HFNC and COT.

Zhou et al. recently reported a systematic review using NMA that compared NPPV, HFNC, and COT in post-extubation patients [49], but their inclusion criteria differ from ours. Zhou et al. included all studies with COPD patients, whereas we excluded studies with $>50 \%$ COPD patients. Moreover, Zhou et al. showed that NPPV was associated with reductions in mortality and post-extubation respiratory failure rates compared to COT. COPD is a risk factor for reintubation after extubation and predisposes patients to hypercapnia during SBT [46]. Thus, NPPV is more effective than COT for patients with hypercapnia after extubation [50], which possibly led to differences in results between our study and that of Zhou et al. Furthermore, including trials with many COPD patients potentially increases the patient heterogeneity. Therefore, we excluded trials where COPD patients accounted for $>50 \%$ of the study population. This study utilized a four-step approach for assessing the certainty of the NMA estimate developed by the GRADE Working Group [51], whereas the study by Zhou et al. did not conduct a similar assessment. A systematic approach using the GRADE system is necessary for evaluating the quality of the evidence to assess whether the evidence is convincing or of low quality, thereby guiding subsequent decision-making.

\section{Implications}

The results of our systematic review are useful for selecting an appropriate noninvasive oxygenation strategy for post-extubation patients because the use of NPPV or HFNC will prevent reintubation in a greater proportion of patients $(66-69$ patients per 1,000) compared to that of СOT. Early weaning from IMV improves patient mortality, whereas reintubation significantly increases mortality risk[3]. Therefore, it is important to choose an appropriate strategy to prevent reintubation after extubation. Both NPPV and HFNC are associated with a lower reintubation rate than COT; therefore, physicians can choose a strategy according to the patient's respiratory physiology status and wishes.

\section{Limitations}

Our systematic review using NMA has several limitations. First, we combined studies that included patients with different etiological conditions necessitating intubation, which may have increased the heterogeneity of the studies. Despite excluding RCTs with $>50 \%$ of patients with postoperative intubation and COPD, the inclusion of a fixed number of postoperative and COPD patients may have influenced the results. Second, we combined studies with different degrees of respiratory failure during the extubation of patients. The effect of NPPV and HFNC may differ depending on illness severity, and differences in severity may be an effect modifier. This NMA included other RCTs, with different characteristics, such as duration of intubation, risk factors for reintubation after extubation, and methods of SBT, which may also be effect modifiers. Third, because only one RCT directly compared NPPV and HFNC, there may not have been a significant difference due to insufficient sample size; there were no significant differences in mortality or post-extubation respiratory failure rates, but this may have been different if the 
sample size was larger. There was incoherence between direct and indirect estimation in the pairwise comparison of NPPV and HFNC, which led to a grading down of network estimation due to the lack of RCTs that directly compared NPPV and HFNC.

\section{Conclusion}

In conclusion, noninvasive respiratory support strategies may be associated with a lower reintubation rate compared with COT, but not shortterm mortality risk.

\section{Abbreviations}

ARF: acute respiratory failure

CENTRAL: Cochrane Central Register of Controlled Trials

Cl: confidence interval

COPD: chronic obstructive pulmonary disease

COT: conventional oxygen therapy

DNR: do-not-resuscitate

ICU: intensive care unit

HFNC: high-flow nasal cannula oxygenation

IMV: invasive mechanical ventilation

NPPV: noninvasive positive-pressure ventilation

NMA: network meta-analysis

PRISMA: Preferred Reporting Items for Systematic review and Meta-Analyses

RCT: randomized controlled trial

RevMan: Review Manager

RR: relative risk

SBT: spontaneous breathing trial

SUCRA: surface under the cumulative ranking curve

\section{Declarations}

\section{Ethics approval and consent to participate:}

Not applicable

Consent for publication:

Not applicable

Availability of data and materials:

The datasets generated during and/or analyzed during the current study are not publicly available due to post-hoc analyses by co-authors but are available from the corresponding author on reasonable request.

Competing interests:

The authors declare that they have no competing interests.

Funding: 
There was no funding source for this study.

\section{Authors' contributions}

$\mathrm{HY}$ participated in the study design, data acquisition, statistical analyses and interpretation of results, and manuscript writing. HO, TM, and YO contributed to the study conception and participated in the data acquisition, interpretation of results, and manuscript writing. $\mathrm{CN}$ contributed to the study conception and participated in the study design, data acquisition, interpretation of results, and manuscript writing. MN and NS contributed to the study conception and participated in the study design, interpretation of results, and manuscript writing.

There is a discrepancy between the findings of this review and those indicated by PROSPERO data because the update of PROSPERO was not completed in time for the submission of this review. All authors in this review meet the International Committee of Medical Journal Editors (ICMJE) criteria.

\section{Acknowledgements:}

We thank Editage for proofreading this manuscript. This study did not receive funding.

\section{References}

1. Schettino G, Altobelli N, Kacmarek RM. Noninvasive positive-pressure ventilation in acute respiratory failure outside clinical trials: experience at the Massachusetts General Hospital. Crit Care Med. 2008;36:441-7.

2. Thille AW, Richard JC, Brochard L. The decision to extubate in the intensive care unit. Am J Respir Crit Care Med. 2013;187:1294-302.

3. Sellares J, Ferrer M, Cano E, Loureiro H, Valencia M, Torres A. Predictors of prolonged weaning and survival during ventilator weaning in a respiratory ICU. Intensive Care Med. 2011;37:775-84.

4. Delclaux C, L'Her E, Alberti C, Mancebo J, Abroug F, Conti G, et al. Treatment of acute hypoxemic nonhypercapnic respiratory insufficiency with continuous positive airway pressure delivered by a face mask: a randomized controlled trial. JAMA. 2000;284:2352-60.

5. Confalonieri M, Potena A, Carbone G, Porta RD, Tolley EA, Umberto Meduri G. Acute respiratory failure in patients with severe communityacquired pneumonia. a prospective randomized evaluation of noninvasive ventilation. Am J Respir Crit Care Med. 1999;160:1585-91.

6. Ferrer M, Valencia M, Nicolas JM, Bernadich O, Badia JR, Torres A. Early noninvasive ventilation averts extubation failure in patients at risk: a randomized trial. Am J Respir Crit Care Med. 2006;173:164-70.

7. Nava S, Gregoretti C, Fanfulla F, Squadrone E, Grassi M, Carlucci A, et al. Noninvasive ventilation to prevent respiratory failure after extubation in high-risk patients. Crit Care Med. 2005;33:2465-70.

8. Glossop AJ, Shephard N, Bryden DC, Mills GH. Noninvasive ventilation for weaning, avoiding reintubation after extubation and in the postoperative period: a meta-analysis. Br J Anaesth. 2012;109:305-14.

9. Agarwal R, Aggarwal AN, Gupta D, Jindal SK. Role of noninvasive positive-pressure ventilation in postextubation respiratory failure: a metaanalysis. Respir Care. 2007;52:1472-9.

10. Ferrer M, Sellares J, Valencia M, Carrillo A, Gonzalez G, Badia JR, et al. Noninvasive ventilation after extubation in hypercapnic patients with chronic respiratory disorders: randomised controlled trial. Lancet. 2009;374:1082-8.

11. El-Solh AA, Aquilina A, Pineda L, Dhanvantri V, Grant B, Bouquin P. Noninvasive ventilation for prevention of post-extubation respiratory failure in obese patients. Eur Respir J. 2006;28:588-95.

12. Bello G, De Pascale G, Antonelli M. Noninvasive ventilation. Clin Chest Med. 2016;37:711-21.

13. Hill NS. Complications of noninvasive ventilation. Respir Care. 2000;45:480-1.

14. Fernandez R, Subira C, Frutos-Vivar F, Rialp G, Laborda C, Masclans JR, et al. High-flow nasal cannula to prevent postextubation respiratory failure in high-risk non-hypercapnic patients: a randomized multicenter trial. Ann Intensive Care. 2017;7:47.

15. Hernández G, Vaquero C, González P, Subira C, Frutos-Vivar F, Rialp G, et al. Effect of postextubation high-flow nasal cannula vs conventional oxygen therapy on reintubation in low-risk patients: a randomized clinical trial. JAMA. 2016;315:1354-61.

16. Ni YN, Luo J, Yu H, Liu D, Ni Z, Cheng J, et al. Can High-flow Nasal Cannula Reduce the rate of endotracheal Intubation in Adult Patients With Acute Respiratory Failure Compared With Conventional Oxygen Therapy and Noninvasive Positive Pressure Ventilation?: A Systematic Review and Meta-analysis. Chest. 2017;151:764-75.

17. Zhu Y, Yin H, Zhang R, Ye X, Wei J. High-flow nasal cannula oxygen therapy versus conventional oxygen therapy in patients after planned extubation: a systematic review and meta-analysis. Crit Care. 2019;23:180.

18. Xu Z, Li Y, Zhou J, Li X, Huang Y, Liu X, et al. High-flow nasal cannula in adults with acute respiratory failure and after extubation: a systematic review and meta-analysis. Respir Res. 2018;19:202. 
19. Huang HW, Sun XM, Shi ZH, Chen GQ, Chen L, Friedrich JO, et al. Effect of high-flow nasal cannula oxygen therapy versus conventional oxygen therapy and noninvasive ventilation on reintubation rate in adult patients after extubation: a systematic review and meta-analysis of randomized controlled trials. J Intensive Care Med. 2018;33:609-23.

20. Lin C, Yu H, Fan H, Li Z. The efficacy of noninvasive ventilation in managing postextubation respiratory failure: a meta-analysis. Heart Lung. 2014;43:99-104.

21. Hutton B, Salanti G, Caldwell DM, Chaimani A, Schmid CH, Cameron C, et al. The PRISMA extension statement for reporting of systematic reviews incorporating network meta-analyses of health care interventions: checklist and explanations. Ann Intern Med. 2015;162:777-84.

22. TC C. Data collection form-intervention review for RCTs only. Secondary data collection form-intervention review for RCTs only. 2014. https ://dplp.cochrane.org/data-extraction-forms (accessed September 8, 2020).

23. TC C. RevMan 5 download and installion. Secondary RevMan 5 download and installion. 2014. https://community.cochrane.org/help/toolsand-software/revman-5/revman-5-download/installation (accessed September 8, 2020).

24. TC C. Cochrane handbook for systematic reviews of interventions. 2011. https://training.cochrane.org/handbook (accessed September 8 , 2020).

25. TC C. Table 8.5.d: Criteria for judging risk of bias in the 'Risk of bias' assessment tool. Secondary Table 8.5.d: Criteria for judging risk of bias in the 'Risk of bias' assessment tool. 2011. http://handbook-5-1.cochrane.org (accessed September 8, 2020).

26. Higgins JP, Thompson SG. Quantifying heterogeneity in a meta-analysis. Stat Med. 2002;21:1539-58.

27. Sterne JA, Sutton AJ, loannidis JP, Terrin N, Jones DR, Lau J, et al. Recommendations for examining and interpreting funnel plot asymmetry in meta-analyses of randomised controlled trials. BMJ. 2011;343:d4002.

28. Salanti G, Ades AE, loannidis JP. Graphical methods and numerical summaries for presenting results from multiple-treatment meta-analysis: an overview and tutorial. J Clin Epidemiol. 2011;64:163-71.

29. Rhodes KM, Turner RM, Higgins JP. Predictive distributions were developed for the extent of heterogeneity in meta-analyses of continuous outcome data. J Clin Epidemiol. 2015;68:52-60.

30. Higgins JP, Jackson D, Barrett JK, Lu G, Ades AE, White IR. Consistency and inconsistency in network meta-analysis: concepts and models for multi-arm studies. Res Synth Methods. 2012;3:98-110.

31. Ornico SR, Lobo SM, Sanches HS, Deberaldini M, Tófoli LT, Vidal AM, et al. Noninvasive ventilation immediately after extubation improves weaning outcome after acute respiratory failure: a randomized controlled trial. Crit Care. 2013;17:R39.

32. Mohamed KAE, Abdalla MH. Role of non invasive ventilation in limiting re-intubation after planned extubation. Egypt $\mathrm{J}$ Chest Dis Tuberc. 2013;62:669-74.

33. Su CL, Chiang LL, Yang SH, Lin HI, Cheng KC, Huang YCT, et al. Preventive use of noninvasive ventilation after extubation: a prospective, multicenter randomized controlled trial. Respir Care. 2012;57:204-10.

34. Thanthitaweewat V, Muntham D, Chirakalwasan N. Targeted-volume noninvasive ventilation reduces extubation failure in postextubated medical intensive care unit patients: a randomized controlled trial. Indian J Crit Care Med. 2018;22:639-45.

35. Arman PD, Varn MN, Povian S, Davis A, Uchakin P, Bhar A, et al. Effects of direct extubation to high-flow nasal cannula compared to standard nasal cannula in patients in the intensive care unit. InA53. Critical care: problems related to intubation, weaning, and extubation. 2017 May (pp. A1887). American Thoracic Society.

36. Hernández G, Vaquero C, Colinas L, Cuena R, González P, Canabal A, et al. Effect of postextubation high-flow nasal cannula vs noninvasive ventilation on reintubation and postextubation respiratory failure in high-risk patients: a randomized clinical trial. JAMA. 2016;316:156574.

37. Song HZ, Gu JX, Xiu HQ, Cui W, Zhang GS. The value of high-flow nasal cannula oxygen therapy after extubation in patients with acute respiratory failure. Clinics. 2017;72:562-7.

38. Maggiore SM, Idone FA, Vaschetto R, Festa R, Cataldo A, Antonicelli F, et al. Nasal high-flow versus Venturi mask oxygen therapy after extubation. effects on oxygenation, comfort, and clinical outcome. Am J Respir Crit Care Med. 2014;190:282-8.

39. Cho JY, Kim HS, Kang H, Kim SH, Choe KH, Lee KM, et al. Comparison of postextubation outcomes associated with high-flow nasal cannula vs. conventional oxygen therapy in patients at high risk of reintubation: a randomized clinical trial. J Korean Med Sci. 2020;35:25:e194

40. Hu TY, Lee CH, Cheng KH, Tan MC, Hua HF, Kuo LK. Effect of high-flow nasal oxygen vs. Conventional oxygen therapy on extubation outcomes and physiologic changes for patients with high risk of extubation failure in the medical ICU: a tertiary center, randomized, controlled trial. J Intensive Care Med. 2020;14:36-41.

41. Matsuda W, Hagiwara A, Uemura T, Sato T, Kobayashi K, Sasaki R, et al. High-glow nasal cannula may not reduce the intubation rate compared with a large-volume nebulization-based humidifier. Respir Care. 2020;65:5:610-7.

42. Theerawit P, Natpobsuk N, Petnak T, Sutherasan Y. The efficacy of the WhisperFlow CPAP system versus high flow nasal cannula in patients at risk for postextubation failure: a randomized controlled trial. J Crit Care 2020;S0883-9441 (20)30710-3 [Online ahead of print].

Page 9/19 
43. Bajaj A, Rathor P, Sehgal V, Shetty A. Efficacy of noninvasive ventilation after planned extubation: A systematic review and meta-analysis of randomized controlled trials. Heart Lung. 2015;44:150-7.

44. Ou J, Chen H, Li L, Zhao L, Nie N. The role of noninvasive ventilation used immediately after planned extubation for adults with chronic respiratory disorders. Saudi Med J. 2018;39:131-6.

45. Kondo Y, Kumasawa J, Kawaguchi A, Seo R, Nango E, Hashimoto S. Effects of noninvasive ventilation in patients with acute respiratory failure excluding post-extubation respiratory failure, cardiogenic pulmonary edema and exacerbation of COPD: a systematic review and meta-analysis. J Anesth. 107;31:714-25.

46. Chu CC, Liu CJ, Yen SM, Chou WY, Kung PT, Tsai YS, et al. Factors associated with re-intubation within 14 days after ventilator liberation. Respir Care. 2017;62:1557-64.

47. Parke R, McGuinness S, Dixon R, Jull A. Open-label, phase II study of routine high-flow nasal oxygen therapy in cardiac surgical patients. Br J Anaesth. 2013;111:925-31.

48. Moscona R, Berger J, Govrin J. Large skull defect in aplasia cutis congenita treated by pericranial flap: long-term follow-up. Ann Plast Surg. 1991;26:178-82.

49. Zhou X, Yao S, Dong P, Chen B, Xu Z, Wang H. Preventive use of respiratory support after scheduled extubation in critically ill medical patients-a network meta-analysis of randomized controlled trials. Crit Care. 2020;24:370.

50. Gong Y, Han X, Duan J, Huang S. Not all COPD patients benefit from prophylactic noninvasive ventilation after scheduled extubation: an exploratory study. Int J Chron Obstruct Pulmon Dis. 2019;14:2809-14.

51. Puhan MA, Schünemann HJ, Murad MH, Li T, Brignardello-Petersen R, Singh JA, et al. A GRADE working group approach for rating the quality of treatment effect estimates from network meta-analysis. BMJ. 2014;349:g5630.

\section{Tables}

Table 1 Study populations, protocols, and study characteristics 


\begin{tabular}{|c|c|c|c|c|c|c|c|c|c|}
\hline \multirow[t]{2}{*}{ Author, year } & \multirow{2}{*}{$\begin{array}{l}\text { Publication } \\
\text { status }\end{array}$} & \multirow{2}{*}{$\begin{array}{l}\text { Sample } \\
\text { size } \\
n\end{array}$} & \multicolumn{3}{|l|}{ Protocols } & \multicolumn{4}{|c|}{ Baseline characteristics } \\
\hline & & & $\begin{array}{l}\text { Intervention } \\
\text { setting }\end{array}$ & $\begin{array}{l}\text { Control } \\
\text { Setting }\end{array}$ & Outcomes & $\begin{array}{l}\text { Age, } \\
\text { years }\end{array}$ & $\begin{array}{l}\mathrm{PaO}_{2}: \mathrm{FiO}_{2} \\
\text { ratio }\end{array}$ & $\begin{array}{l}\text { Main reason } \\
\text { for initiation } \\
\text { of } \\
\text { mechanical } \\
\text { ventilation }\end{array}$ & $\begin{array}{l}\text { Duration } \\
\text { of } \\
\text { intubation, } \\
\text { days }\end{array}$ \\
\hline \multirow{2}{*}{$\begin{array}{l}\text { Ferrer }{ }^{6)} \\
2006\end{array}$} & \multirow[t]{2}{*}{ Published } & \multirow[t]{2}{*}{162} & \multirow[t]{2}{*}{ NPPV } & \multirow[t]{2}{*}{ COT } & $\begin{array}{l}\text { 1. Mortality } \\
\text { (In-hospital) }\end{array}$ & $\begin{array}{l}\text { NPPV: } \\
72 \\
(10)\end{array}$ & $\begin{array}{l}\text { NPPV: } \\
278 \text { (95) }\end{array}$ & \multirow{2}{*}{$\begin{array}{l}\text { Exacerbation } \\
\text { of chronic } \\
\text { respiratory } \\
\text { disorders } \\
{[30.2 \%]}\end{array}$} & \multirow{2}{*}{$\begin{array}{l}\text { NPPV: } 6 \\
(4) \\
\text { COT: } 7 \text { (5) }\end{array}$} \\
\hline & & & & & $\begin{array}{l}\text { 2. } \\
\text { Reintubation } \\
\text { 3. } \\
\text { Respiratory } \\
\text { failure }\end{array}$ & $\begin{array}{l}\text { COT: } \\
70 \\
(11)\end{array}$ & $\begin{array}{l}\text { COT: } 276 \\
(94)\end{array}$ & & \\
\hline \multirow{3}{*}{$\begin{array}{l}\mathrm{Su}^{33)} \\
2012\end{array}$} & \multirow[t]{3}{*}{ Published } & \multirow[t]{3}{*}{406} & \multirow[t]{3}{*}{ NPPV } & \multirow[t]{3}{*}{ COT } & $\begin{array}{l}\text { 1. Mortality } \\
\text { (In-ICU) }\end{array}$ & $\begin{array}{l}\text { NPPV: } \\
65 \text { (1) }\end{array}$ & NA & \multirow{3}{*}{$\begin{array}{l}\text { Postoperative } \\
\text { respiratory } \\
\text { failure } \\
{[24.4 \%]}\end{array}$} & \multirow[t]{3}{*}{ NA } \\
\hline & & & & & $\begin{array}{l}2 . \\
\text { Reintubation }\end{array}$ & $\begin{array}{l}\text { COT: } \\
63(1)\end{array}$ & & & \\
\hline & & & & & $\begin{array}{l}3 . \\
\text { Respiratory } \\
\text { failure }\end{array}$ & & & & \\
\hline \multirow{2}{*}{$\begin{array}{l}\text { Mohamed }{ }^{32)} \\
2013\end{array}$} & \multirow[t]{2}{*}{ Published } & \multirow[t]{2}{*}{120} & \multirow[t]{2}{*}{ NPPV } & \multirow[t]{2}{*}{ COT } & \multirow[t]{2}{*}{$\begin{array}{l}\text { 1. Mortality } \\
\text { (In-ICU) }\end{array}$} & $\begin{array}{l}\text { NPPV: } \\
64 \text { (7) }\end{array}$ & \multirow[t]{2}{*}{ NA } & \multirow[t]{2}{*}{ COPD [29.2\%] } & $\begin{array}{l}\text { NPPV: } 6.2 \\
\text { (1.6) }\end{array}$ \\
\hline & & & & & & $\begin{array}{l}\text { COT: } \\
69(7)\end{array}$ & & & $\begin{array}{l}\text { COT: } 7.1 \\
(1.8)\end{array}$ \\
\hline \multirow{2}{*}{$\begin{array}{l}\text { Orico }{ }^{31)} \\
2013\end{array}$} & \multirow[t]{2}{*}{ Published } & \multirow[t]{2}{*}{38} & \multirow[t]{2}{*}{ NPPV } & \multirow[t]{2}{*}{ COT } & \multirow{2}{*}{$\begin{array}{l}\text { 1. Mortality } \\
\text { (In-hospital) } \\
2 . \\
\text { Reintubation }\end{array}$} & $\begin{array}{l}\text { NPPV: } \\
51 \\
(18)\end{array}$ & NA & $\begin{array}{l}\text { Pneumonia } \\
\text { [84.2\%] }\end{array}$ & $\begin{array}{l}\text { NPPV: } 9.9 \\
(8.1)\end{array}$ \\
\hline & & & & & & $\begin{array}{l}\text { COT: } \\
49 \\
(22)\end{array}$ & & & $\begin{array}{l}\text { COT: } 9.5 \\
(6.1)\end{array}$ \\
\hline Maggiore ${ }^{38)}$ & Published & 105 & HFNC & COT & $\begin{array}{l}\text { 1. Mortality } \\
\text { (In-ICU) }\end{array}$ & $\begin{array}{l}\text { HFNC: } \\
65 \\
(18)\end{array}$ & $\begin{array}{l}\text { HFNC: } \\
239 \text { (42) }\end{array}$ & $\begin{array}{l}\text { Pneumonia } \\
{[45.7 \%]}\end{array}$ & $\begin{array}{l}\text { HFNC: } 4.6 \\
(4.1)\end{array}$ \\
\hline 2014 & & & & & $\begin{array}{l}2 . \\
\text { Reintubation }\end{array}$ & $\begin{array}{l}\text { COT } \\
64 \\
(17)\end{array}$ & $\begin{array}{l}\text { COT: } 242 \\
\text { (51) }\end{array}$ & & $\begin{array}{l}\text { COT: } 5.2 \\
(3.7)\end{array}$ \\
\hline Hernandez $\left.{ }^{15}\right)$ & Published & 527 & HFNC & COT & $\begin{array}{l}\text { 1. Mortality } \\
\text { (In-hospital) }\end{array}$ & $\begin{array}{l}\text { HFNC: } \\
51 \\
(13)\end{array}$ & $\begin{array}{l}\text { HFNC: } \\
227 \text { (25) }\end{array}$ & $\begin{array}{l}\text { Urgent } \\
\text { surgery } \\
{[24.9 \%]}\end{array}$ & $\begin{array}{l}\text { HFNC: } 1 \\
{ }^{[1-3]^{a}}\end{array}$ \\
\hline $2010(1)$ & & & & & $\begin{array}{l}2 . \\
\text { Reintubation } \\
3 . \\
\text { Respiratory } \\
\text { failure }\end{array}$ & $\begin{array}{l}\text { COT: } \\
52 \\
(12)\end{array}$ & $\begin{array}{l}\text { COT: } 237 \\
\text { (34) }\end{array}$ & & $\begin{array}{l}\text { COT: } 2 \\
{[1-4]^{a}}\end{array}$ \\
\hline $\begin{array}{l}\text { Hernandez } \\
\end{array}$ & Published & 604 & NPPV & HFNC & $\begin{array}{l}\text { 1. Mortality } \\
\text { (In-hospital) }\end{array}$ & $\begin{array}{l}\text { NPPV: } \\
64 \\
(16)\end{array}$ & $\begin{array}{l}\text { NPPV: } \\
194 \text { (37) }\end{array}$ & $\begin{array}{l}\text { Urgent } \\
\text { surgery } \\
{[31.5 \%]}\end{array}$ & $\begin{array}{l}\text { NPPV: } 4 \\
{[2-8]^{a}}\end{array}$ \\
\hline $2010(2)$ & & & & & $\begin{array}{l}2 . \\
\text { Reintubation } \\
3 . \\
\text { Respiratory } \\
\text { failure }\end{array}$ & $\begin{array}{l}\text { HFNC: } \\
65 \\
(15)\end{array}$ & $\begin{array}{l}\text { HFNC: } \\
191 \text { (34) }\end{array}$ & & $\begin{array}{l}\text { HFNC: } 4 \\
{[2-9]^{a}}\end{array}$ \\
\hline Arman ${ }^{35)}$ & Unpublished & 15 & HFNC & COT & $\begin{array}{l}\text { 1. Mortality } \\
\text { (30 days) }\end{array}$ & NA & NA & AHRF & NA \\
\hline 2017 & & & & & $\begin{array}{l}2 . \\
\text { Reintubation }\end{array}$ & & & & \\
\hline Fernandez ${ }^{14)}$ & Published & 155 & HFNC & COT & $\begin{array}{l}\text { 1. Mortality } \\
\text { (In-ICU, In- }\end{array}$ & $\begin{array}{l}\text { HFNC: } \\
67\end{array}$ & NA & AHRF & $\begin{array}{l}\text { HFNC: } 8.2 \\
(5.9)\end{array}$ \\
\hline 2017 & & & & & & & & & $\begin{array}{l}\text { COT: } 7.4 \\
(3.6)\end{array}$ \\
\hline
\end{tabular}

Page 11/19 


\begin{tabular}{|c|c|c|c|c|c|c|c|c|c|}
\hline & & & & & $\begin{array}{l}2 . \\
\text { Reintubation } \\
3 . \\
\text { Respiratory } \\
\text { failure }\end{array}$ & $\begin{array}{l}\text { COT: } \\
70 \\
(13)\end{array}$ & & & \\
\hline \multirow{3}{*}{$\begin{array}{l}\text { Song }{ }^{37)} \\
2017\end{array}$} & \multirow[t]{3}{*}{ Published } & \multirow[t]{3}{*}{60} & \multirow[t]{3}{*}{ HFNC } & \multirow[t]{3}{*}{ COT } & \multirow[t]{3}{*}{$\begin{array}{l}1 . \\
\text { Reintubation }\end{array}$} & \multirow{2}{*}{$\begin{array}{l}\text { HFNC: } \\
66 \\
(14)\end{array}$} & \multirow[t]{3}{*}{ NA } & \multirow[t]{3}{*}{$\begin{array}{l}\text { Pneumonia } \\
\text { [41.7\%] }\end{array}$} & \multirow{3}{*}{$\begin{array}{l}\text { HFNC: } 5.5 \\
(3.4) \\
\text { COT: } 5.4 \\
(2.8)\end{array}$} \\
\hline & & & & & & & & & \\
\hline & & & & & & $\begin{array}{l}\text { COT } \\
71 \\
(13)\end{array}$ & & & \\
\hline $\begin{array}{l}\text { Thanthiaweewat } \\
\text { 34) }\end{array}$ & Published & 58 & NPPV & СOT & $\begin{array}{l}\text { 1. Mortality } \\
\text { (28 days) }\end{array}$ & $\begin{array}{l}\text { NPPV: } \\
63 \\
(22)\end{array}$ & $\begin{array}{l}\text { NPPV: } \\
330 \text { (104) }\end{array}$ & $\begin{array}{l}\text { Pneumonia } \\
\text { [58.6\%] }\end{array}$ & $\begin{array}{l}\text { NPPV: } 4 \\
{[5]^{a}}\end{array}$ \\
\hline 2018 & & & & & $\begin{array}{l}2 . \\
\text { Reintubation }\end{array}$ & $\begin{array}{l}\text { COT: } \\
63 \\
(19)\end{array}$ & $\begin{array}{l}\text { COT: } 359 \\
(179)\end{array}$ & & $\begin{array}{l}\text { COT: } 7 \text { [7] } \\
\text { a }\end{array}$ \\
\hline \multirow{2}{*}{$\begin{array}{l}\text { Cho }{ }^{39)} \\
2020\end{array}$} & \multirow[t]{2}{*}{ Published } & \multirow[t]{2}{*}{60} & \multirow[t]{2}{*}{ HFNC } & \multirow[t]{2}{*}{ СОТ } & \multirow{2}{*}{$\begin{array}{l}\text { 1. Mortality } \\
\text { (In-ICU, In- } \\
\text { hospital) } \\
2 . \\
\text { Reintubation }\end{array}$} & $\begin{array}{l}\text { HFNC: } \\
79(8)\end{array}$ & $\begin{array}{l}\text { HFNC: } \\
272 \text { (99) }\end{array}$ & \multirow[t]{2}{*}{$\begin{array}{l}\text { Pneumonia } \\
\text { [66.7\%] }\end{array}$} & $\begin{array}{l}\text { HFNC: } 7.1 \\
(4.7)\end{array}$ \\
\hline & & & & & & $\begin{array}{l}\text { COT } \\
77(7)\end{array}$ & $\begin{array}{l}\text { COT } 297 \\
(119)\end{array}$ & & $\begin{array}{l}\text { COT } 5.7 \\
(5.2)\end{array}$ \\
\hline \multirow[t]{2}{*}{$\begin{array}{l}\mathrm{Hu}{ }^{40)} \\
2020\end{array}$} & \multirow[t]{2}{*}{ Published } & \multirow[t]{2}{*}{56} & \multirow[t]{2}{*}{ HFNC } & \multirow[t]{2}{*}{ СОТ } & $\begin{array}{l}\text { 1. Mortality } \\
\text { (In-hospital) }\end{array}$ & $\begin{array}{l}\text { HFNC: } \\
73 \\
(13)\end{array}$ & $\begin{array}{l}\text { HFNC: } \\
320(90)\end{array}$ & \multirow[t]{2}{*}{$\begin{array}{l}\text { Pneumonia } \\
{[39.3 \%]}\end{array}$} & $\begin{array}{l}\text { HFNC: } 9 \\
{[6]^{a}}\end{array}$ \\
\hline & & & & & $\begin{array}{l}2 . \\
\text { Reintubation } \\
3 . \\
\text { Respiratory } \\
\text { failure }\end{array}$ & $\begin{array}{l}\text { COT } \\
75 \\
(11)\end{array}$ & $\begin{array}{l}\text { COT } 279 \\
(91)\end{array}$ & & $\begin{array}{l}\text { COT: } 7 \text { [4] } \\
\text { a }\end{array}$ \\
\hline \multirow{2}{*}{$\begin{array}{l}\text { Matsuda }{ }^{41)} \\
2020\end{array}$} & \multirow[t]{2}{*}{ Published } & \multirow[t]{2}{*}{69} & \multirow[t]{2}{*}{ HFNC } & \multirow[t]{2}{*}{ СOT } & \multirow[t]{2}{*}{$\begin{array}{l}1 . \\
\text { Reintubation }\end{array}$} & \multirow[t]{2}{*}{$\begin{array}{l}\text { HFNC: } \\
72 \\
(18)\end{array}$} & $\begin{array}{l}\text { HFNC: } \\
227 \text { (43) }\end{array}$ & \multirow[t]{2}{*}{$\begin{array}{l}\text { Pneumonia } \\
{[53.6 \%]}\end{array}$} & $\begin{array}{l}\text { HFNC: } 5 \\
(2)\end{array}$ \\
\hline & & & & & & & $\begin{array}{l}\text { COT } 216 \\
(37)\end{array}$ & & СOT 6 (3) \\
\hline \multirow{2}{*}{$\begin{array}{l}\left.\text { Theerawit }{ }^{42}\right) \\
2020\end{array}$} & \multirow[t]{2}{*}{ Published } & \multirow[t]{2}{*}{140} & \multirow[t]{2}{*}{ HFNC } & \multirow[t]{2}{*}{ СOT } & $\begin{array}{l}\text { 1. Mortality } \\
\text { (In-hospital) }\end{array}$ & $\begin{array}{l}\text { HFNC: } \\
68 \\
(19)\end{array}$ & $\begin{array}{l}\text { HFNC: } \\
298(96)\end{array}$ & $\begin{array}{l}\text { Pneumonia } \\
\text { [59.3\%] }\end{array}$ & $\begin{array}{l}\text { HFNC: } 6.9 \\
(4.9)\end{array}$ \\
\hline & & & & & $\begin{array}{l}2 . \\
\text { Reintubation } \\
3 . \\
\text { Respiratory } \\
\text { failure }\end{array}$ & $\begin{array}{l}\text { COT } \\
71 \\
(16)\end{array}$ & $\begin{array}{l}\text { COT } 289 \\
(114)\end{array}$ & & $\begin{array}{l}\text { COT } 6.2 \\
(4.0)\end{array}$ \\
\hline
\end{tabular}

AHRF, acute hypoxic respiratory failure; COPD, chronic obstructive pulmonary disease; COT, conventional oxygen therapy; ICU, intensive care unit; HFNC, high flow nasal cannula; NPPV, noninvasive positive pressure ventilation

Continuous data are shown as mean and standard deviation, except for data labeled with "a".

a: Data reported as median and IQR (interquartile range).

Table 2 Summary of findings for short-term mortality from the network meta-analysis 
Estimates of effects, credible intervals, and certainty of the evidence for oxygen therapy after extubation in patients recovering from sepsis

\section{BENEFITS}

Patients or population: patients with sepsis after extubation

Interventions: One of the following oxygen therapies: NPPV, HFNC, or COT

Comparator (reference): One therapy other than the therapy included in intervention

Outcome: Short-term mortality

Setting: In-hospital

Frequency NMA-SoF table

\begin{tabular}{|c|c|c|c|c|c|c|c|}
\hline - & & & & & $1 \mathrm{RC}$ & pants & 1818 participants \\
\hline \multirow{2}{*}{$\begin{array}{l}\text { Total studies: } 13 \\
\text { Total Patients: } 2,446\end{array}$} & \multirow{2}{*}{$\begin{array}{l}\text { Relative effect } \\
(95 \% \mathrm{CI})^{* *}\end{array}$} & \multicolumn{3}{|c|}{ Anticipated absolute effect $(95 \% \mathrm{CI})^{* * *}$} & \multirow{2}{*}{$\begin{array}{l}\text { Certainty of } \\
\text { the evidence }\end{array}$} & \multirow{2}{*}{$\begin{array}{c}\text { MeanRank**** } \\
\text { (SUCRA) }\end{array}$} & \multirow{2}{*}{$\begin{array}{l}\text { Interpretation of } \\
\text { findings }\end{array}$} \\
\hline & & Without intervention & With intervention & Difference & & & \\
\hline $\begin{array}{l}\text { NPPV } \\
\text { (5 RCT; } 784 \\
\text { participants) }\end{array}$ & $\begin{array}{c}0.75 \\
(0.53 \text { to } 1.06) \\
\text { Network } \\
\text { estimate }\end{array}$ & 104 per 1000 & 78 per 1000 & $\begin{array}{c}26 \text { fewer per } \\
1000 \\
\text { (49 fewer to } 6 \\
\text { more) }\end{array}$ & $\begin{array}{c}\oplus \oplus \bigcirc \bigcirc \\
\text { Low }^{2}\end{array}$ & $\begin{array}{c}1.1 \\
(93.2)\end{array}$ & $\begin{array}{l}\text { Probably } \\
\text { superior }\end{array}$ \\
\hline $\begin{array}{l}\text { HFNC } \\
\text { (7 RCT; } 1058 \\
\text { participants) }\end{array}$ & $\begin{array}{c}0.92 \\
(0.67 \text { to } 1.27)\end{array}$ & 84 per 1000 & 77 per 1000 & $\begin{array}{c}7 \text { fewer per } \\
1000\end{array}$ & $\begin{array}{c}\oplus \oplus \oplus \bigcirc \\
\text { Moderate }^{b}\end{array}$ & $\begin{array}{c}2.3 \\
(36.7)\end{array}$ & $\begin{array}{l}\text { Probably } \\
\text { superior }\end{array}$ \\
\hline
\end{tabular}

\begin{tabular}{|c|c|c|c|c|c|c|c|}
\hline & $\begin{array}{l}\text { Network } \\
\text { estimate }\end{array}$ & & & $\begin{array}{c}\text { (28 fewer to } 23 \\
\text { more) }\end{array}$ & & & \\
\hline $\mathrm{COT}$ & $\begin{array}{l}\text { Reference } \\
\text { comparator }\end{array}$ & No estimable & No estimable & No estimable & $\begin{array}{l}\text { Reference } \\
\text { comparator }\end{array}$ & $\begin{array}{c}2.6 \\
(20.1) \\
\end{array}$ & $\begin{array}{l}\text { Reference } \\
\text { comparator }\end{array}$ \\
\hline $\begin{array}{l}\text { NPPV } \\
\text { (1 RCT; } 604 \\
\text { participants) }\end{array}$ & $\begin{array}{c}0.81 \\
\text { (0.61 to } 1.08) \\
\text { Network } \\
\text { estimate }\end{array}$ & 203 per 1000 & 164 per 1000 & $\begin{array}{c}39 \text { fewer per } \\
1000 \\
\text { (79 fewer to } 16 \\
\text { more) }\end{array}$ & $\begin{array}{c}\oplus \oplus \oplus \bigcirc \\
\text { Moderate }^{b}\end{array}$ & - & $\begin{array}{l}\text { Probably } \\
\text { superior }\end{array}$ \\
\hline HFNC & $\begin{array}{l}\text { Reference } \\
\text { comparator }\end{array}$ & No estimable & No estimable & No estimable & $\begin{array}{l}\text { Reference } \\
\text { comparator }\end{array}$ & $\begin{array}{l}\text { Reference } \\
\text { comparator }\end{array}$ & $\begin{array}{l}\text { Reference } \\
\text { comparator }\end{array}$ \\
\hline \multicolumn{8}{|c|}{$\begin{array}{l}\text { NMA, network meta-analysis: NPPV, non-invasive positive pressure ventilation; HFNC, high-flow nasal cannula; COT, conventional oxygen therapy; SOF, } \\
\text { summary of findings: SUCRA, surface under the cumulative ranking }\end{array}$} \\
\hline \multicolumn{8}{|c|}{ NMA-SoF table definitions } \\
\hline \multicolumn{8}{|c|}{${ }^{*}$ Lines represent direct comparisons } \\
\hline \multicolumn{8}{|c|}{ ** Estimates are reported as risk ratio. CI: confidence interval. } \\
\hline \multicolumn{8}{|c|}{$\begin{array}{l}\text { *** Anticipated absolute effect. Anticipated absolute effect compares two risks by calculating the difference between the risks in the intervention and control } \\
\text { groups. }\end{array}$} \\
\hline \multicolumn{8}{|c|}{$\begin{array}{l}\text { **** Rank for efficacy outcomes are presented. Rank statistics are defined as the probabilities that one treatment out of } n \text { treatments in a network meta-analysis is } \\
\text { the best, the second best, the third best, and so on, until the least effective treatment. }\end{array}$} \\
\hline \multicolumn{8}{|c|}{ GRADE Working Group grades of evidence (or certainty in the evidence) } \\
\hline \multicolumn{8}{|c|}{ High quality: We are very confident that the true effect lies close to that of the estimate of the effect. } \\
\hline
\end{tabular}


Moderate quality: we are moderately confident in the effect estimate: The true effect is likely close to the estimate of the effect, but there is a possibility that it is substantially different

Low quality: Our confidence in the effect estimate is limited: The true effect may be substantially different from the estimate of the effect.

Very low quality: We have very little confidence in the effect estimate: The true effect is likely to be substantially different from the estimate effect

Explanatory Footnotes

a) Confidence interval extends into clinically important effects in both directions.

b) Confidence interval extends into clinically important effects.

Table 3 Confidence in the relative risk of each comparison and outcome assessed by the GRADE system for short-term mortality, reintubation, and post-extubation respiratory failure

\begin{tabular}{|c|c|c|c|c|c|c|c|}
\hline \multicolumn{8}{|c|}{ Short-term mortality } \\
\hline & $\begin{array}{l}\text { Risk of bias across } \\
\text { studies }\end{array}$ & Imprecision & Heterogeneity & Indirectness & $\begin{array}{l}\text { Publication } \\
\text { bias }\end{array}$ & Incoherence & $\begin{array}{l}\text { Confidence in relative } \\
\text { risk of the event }\end{array}$ \\
\hline $\begin{array}{l}\text { NIV vs. } \\
\text { COT }\end{array}$ & Undetected & $\begin{array}{l}\left.\text { Very serious }{ }^{a}\right) \\
(95 \% \text { Cl } 0.53- \\
1.06)\end{array}$ & $\begin{array}{l}\text { No concern } \\
\text { (95\% PI 0.51- } \\
1.11)\end{array}$ & Low & $\begin{array}{l}\text { Not } \\
\text { suggested }\end{array}$ & $\begin{array}{l}\text { No concern } \\
(p=0.33)\end{array}$ & $\begin{array}{l}\oplus \oplus \bigcirc \bigcirc \\
\text { Low }\end{array}$ \\
\hline $\begin{array}{l}\text { HFNC vs. } \\
\text { COT }\end{array}$ & Undetected & $\begin{array}{l}\left.\text { Serious }^{b}\right) \\
(95 \% \text { Cl 0.67- } \\
1.27)\end{array}$ & $\begin{array}{l}\text { No concern } \\
\text { (95\% PI 0.64- } \\
1.33)\end{array}$ & Low & $\begin{array}{l}\text { Not } \\
\text { suggested }\end{array}$ & $\begin{array}{l}\text { No concern } \\
(p=0.33)\end{array}$ & $\begin{array}{l}\bigoplus \oplus \bigoplus \bigcirc \\
\text { Moderate }\end{array}$ \\
\hline $\begin{array}{l}\text { HFNC vs. } \\
\text { NIV }\end{array}$ & Undetected & $\begin{array}{l}\left.\text { Serious }^{\mathrm{b}}\right) \\
(95 \% \mathrm{Cl} 0.61- \\
1.08)\end{array}$ & $\begin{array}{l}\text { No concern } \\
\text { (95\% PI 0.58- } \\
1.13)\end{array}$ & Low & $\begin{array}{l}\text { Not } \\
\text { suggested }\end{array}$ & $\begin{array}{l}\text { No concern } \\
(p=0.33)\end{array}$ & $\begin{array}{l}\oplus \oplus \bigoplus \bigcirc \\
\text { Moderate }\end{array}$ \\
\hline \multicolumn{8}{|c|}{ Reintubation } \\
\hline $\begin{array}{l}\text { NIV vs. } \\
\text { COT }\end{array}$ & Undetected & $\begin{array}{l}\text { Serious }^{b)} \\
(95 \% \text { Cl 0.30- } \\
1.00)\end{array}$ & $\begin{array}{l}\begin{array}{l}\text { Some } \\
\text { concern }\end{array} \\
\text { c) } \\
(95 \% \text { PI 0.16- } \\
1.84)\end{array}$ & Low & $\begin{array}{l}\text { Not } \\
\text { suggested }\end{array}$ & $\begin{array}{l}\text { No concern } \\
(p=0.58)\end{array}$ & $\begin{array}{l}\bigoplus \oplus \bigoplus \bigcirc \\
\text { Moderate }\end{array}$ \\
\hline $\begin{array}{l}\text { HFNC vs. } \\
\text { COT }\end{array}$ & Undetected & $\begin{array}{l}\text { Not serious } \\
(95 \% \mathrm{Cl} 0.32- \\
0.89)\end{array}$ & $\begin{array}{l}\text { Major } \\
\text { concern d) } \\
(95 \% \text { PI 0.17- } \\
1.70)\end{array}$ & Low & $\begin{array}{l}\text { Not } \\
\text { suggested }\end{array}$ & $\begin{array}{l}\text { No concern } \\
(p=0.58)\end{array}$ & $\begin{array}{l}\bigoplus \bigoplus \bigoplus \bigoplus \\
\text { High }\end{array}$ \\
\hline $\begin{array}{l}\text { HFNC vs. } \\
\text { NIV }\end{array}$ & Undetected & $\begin{array}{l}\text { Very serious }^{\mathrm{a})} \\
(95 \% \mathrm{Cl} 0.53- \\
1.97)\end{array}$ & $\begin{array}{l}\text { No concern } \\
\text { (95\% PI 0.29- } \\
3.55)\end{array}$ & Low & $\begin{array}{l}\text { Not } \\
\text { suggested }\end{array}$ & $\begin{array}{l}\text { No concern } \\
(p=0.58)\end{array}$ & $\begin{array}{l}\oplus \oplus 0 \\
\text { Low }\end{array}$ \\
\hline \multicolumn{8}{|c|}{ Post-extubation respiratory failure } \\
\hline $\begin{array}{l}\text { NIV vs. } \\
\text { COT }\end{array}$ & Undetected & $\begin{array}{l}\left.\text { Very serious }{ }^{a}\right) \\
(95 \% \text { Cl 0.54- } \\
1.38)\end{array}$ & $\begin{array}{l}\text { No concern } \\
\text { (95\% PI 0.29- } \\
2.58)\end{array}$ & Low & $\begin{array}{l}\text { Not } \\
\text { suggested }\end{array}$ & $\begin{array}{l}\text { No concern } \\
(p=0.56)\end{array}$ & $\begin{array}{l}\oplus \oplus \\
\text { Low }\end{array}$ \\
\hline $\begin{array}{l}\text { HFNC vs. } \\
\text { COT }\end{array}$ & Undetected & $\begin{array}{l}\text { Serious }^{b)} \\
(95 \% \text { Cl 0.43- } \\
1.02)\end{array}$ & $\begin{array}{l}\text { Some } \\
\left.\text { concern }{ }^{c}\right) \\
(95 \% \text { PI 0.23- } \\
1.92)\end{array}$ & Low & $\begin{array}{l}\text { Not } \\
\text { suggested }\end{array}$ & $\begin{array}{l}\text { No concern } \\
(p=0.56)\end{array}$ & $\begin{array}{l}\oplus \oplus \bigoplus \bigcirc \\
\text { Moderate }\end{array}$ \\
\hline $\begin{array}{l}\text { HFNC vs. } \\
\text { NIV }\end{array}$ & Undetected & $\begin{array}{l}\text { Very serious }^{a} \text { ) } \\
(95 \% \text { Cl 0.79- } \\
2.14)\end{array}$ & $\begin{array}{l}\text { No concern } \\
\text { (95\% PI 0.42- } \\
3.98)\end{array}$ & Low & $\begin{array}{l}\text { Not } \\
\text { suggested }\end{array}$ & $\begin{array}{l}\text { No concern } \\
(p=0.56)\end{array}$ & $\begin{array}{l}\oplus \oplus 0 \\
\text { Low }\end{array}$ \\
\hline
\end{tabular}

Cl, confidence interval; COT, conventional oxygen therapy; HFNC, high-flow nasal therapy; NIV, non-invasive ventilation; PI, prediction interval

1. Confidence interval extends into clinically important effects in both directions.

Page $14 / 19$ 
2. Confidence interval extends into clinically important effects.

3. Prediction intervalextends into clinically important or unimportant effects.

4. Prediction intervalextends into clinically important effects in both directions.

Table 4 Summary of findings for reintubation from the network meta-analysis

\begin{tabular}{|c|c|c|c|c|c|c|c|}
\hline Estimates of effects, c & ble intervals, and cer & inty of the evidence for & xygen therapy after & xtubation in patients & ecovering from se & Frequency & NMA-SoF table \\
\hline BENEFITS & & & & & & & \\
\hline $\begin{array}{l}\text { Patients or population } \\
\text { Interventions: One of } \\
\text { Comparator (referenc } \\
\text { Outcome: Reintubatio } \\
\text { Setting: In-hospital }\end{array}$ & $\begin{array}{l}\text { ients with sepsis aft } \\
\text { following oxygen the } \\
\text { ne therapy other tha }\end{array}$ & $\begin{array}{l}\text { extubation } \\
\text { apies: NPPV, HFNC, } \\
\text { the therapy included in }\end{array}$ & $\begin{array}{l}\text { OT } \\
\text { tervention }\end{array}$ & & $\begin{array}{l}\text { Network } 1 \\
\text { HFe partici }\end{array}$ & $\mathrm{t}^{*}$ & \\
\hline & & & & & 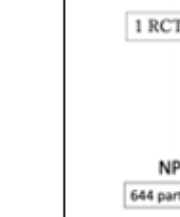 & 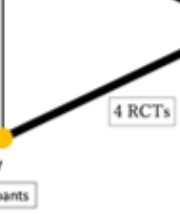 & $\begin{array}{l}\text { с сот } \\
927 \text { participants }\end{array}$ \\
\hline Total studies: 14 & Relative effect & Anticipate & bsolute effect $(95 \%$ & $\mathrm{CI})^{* * *}$ & Certainty of the & MeanRank ${ }^{* * * *}$ & Interpretation \\
\hline Total Patients: 2,455 & $(95 \% \mathrm{CI})^{* *}$ & Without intervention & With intervention & Difference & evidence & (SUCRA) & of findings \\
\hline $\begin{array}{l}\text { NPPV } \\
\text { (4 RCT; } 664 \\
\text { participants) }\end{array}$ & $\begin{array}{c}0.55 \\
(0.30 \text { to } 1.00) \\
\text { Network estimate }\end{array}$ & 138 per 1000 & 76 per 1000 & $\begin{array}{c}62 \text { fewer per } 1000 \\
\text { (96 fewer to } 0 \\
\text { fewer) }\end{array}$ & $\begin{array}{c}\oplus \oplus \oplus \bigcirc \\
\text { Moderate }^{\mathrm{a}}\end{array}$ & $\begin{array}{c}1.6 \\
(71.6)\end{array}$ & $\begin{array}{l}\text { Probably } \\
\text { superior }\end{array}$ \\
\hline \begin{tabular}{|l} 
HFNC \\
(9 RCT; \\
1,187 participants)
\end{tabular} & $\begin{array}{c}0.54 \\
(0.32 \text { to } 0.89) \\
\text { Network estimate }\end{array}$ & 130 per 1000 & 70 per 1000 & $\begin{array}{c}60 \text { fewer per } 1000 \\
\text { (88 fewer to } 14 \\
\text { fewer) }\end{array}$ & $\begin{array}{c}\oplus \oplus \oplus \oplus \\
\text { High }\end{array}$ & $\begin{array}{c}1.5 \\
(75.8)\end{array}$ & $\begin{array}{l}\text { Probably } \\
\text { superior }\end{array}$ \\
\hline $\mathrm{COT}$ & $\begin{array}{l}\text { Reference } \\
\text { comparator }\end{array}$ & No estimable & No estimable & No estimable & $\begin{array}{l}\text { Reference } \\
\text { comparator }\end{array}$ & $\begin{array}{c}2.9 \\
(2.5)\end{array}$ & $\begin{array}{l}\text { Reference } \\
\text { comparator }\end{array}$ \\
\hline
\end{tabular}

\begin{tabular}{|l|l|c|c|c|c|c|c|}
\hline $\begin{array}{l}\text { NPPV } \\
(1 \mathrm{RCT} ; 604 \\
\text { participants })\end{array}$ & $\begin{array}{c}1.02 \\
(0.53 \text { to } 1.97) \\
\text { Network estimate }\end{array}$ & 228 per 1000 & 233 per 1000 & $\begin{array}{c}5 \text { more per } 1000 \\
(107 \text { fewer to } 221 \\
\text { more })\end{array}$ & $\begin{array}{c}\oplus \oplus \bigcirc \bigcirc \\
\text { Low }\end{array}$ & $\begin{array}{c}\text { Probably } \\
\text { equivalent }\end{array}$ \\
\hline HFNC & $\begin{array}{c}\text { Reference } \\
\text { comparator }\end{array}$ & No estimable & No estimable & No estimable & $\begin{array}{c}\text { Reference } \\
\text { comparator }\end{array}$ & $\begin{array}{c}\text { Reference } \\
\text { comparator }\end{array}$ \\
\hline
\end{tabular}

NMA, network meta-analysis: NPPV, non-invasive positive pressure ventilation; HFNC, high-flow nasal cannula; COT, conventional oxygen therapy; SOF, summary of findings: SUCRA, surface under the cumulative ranking

NMA-SoF table definitions

* Lines represent direct comparisons

$*$ Estimates are reported as risk ratio. CI: confidence interval.

*** Anticipated absolute effect. Anticipated absolute effect compares two risks by calculating the difference between the risks in the intervention and control groups.

**** Rank for efficacy outcomes are presented. Rank statistics are defined as the probabilities that one treatment out of $n$ treatments in a network meta-analysis is the best, the second best, the third best, and so on, until the least effective treatment.

GRADE Working Group grades of evidence (or certainty in the evidence)

High quality: We are very confident that the true effect lies close to that of the estimate of the effect.

Moderate quality: we are moderately confident in the effect estimate: The true effect is likely close to the estimate of the effect, but there is a possibility that it is substantially different

Low quality: Our confidence in the effect estimate is limited: The true effect may be substantially different from the estimate of the effect.

Very low quality: We have very little confidence in the effect estimate: The true effect is likely to be substantially different from the estimate effect

Explanatory Footnotes

a) Confidence interval extends into clinically important effects.

b) Confidence interval extends into clinically important effects in both directions. 
Estimates of effects, credible intervals, and certainly of the evidence for oxygen therapy after extubation in patients recovering from sepsis

Frequency NMA-SoF table

\section{BENEFITS}

Patients or population: septic patients after extubation

Interventions: One of the following oxygen therapies: NPPV, HFNT, or COT

Comparator (reference): One of the other therapies other than the therapy included in intervention

Outcome: Post-extubation Respiratory failure

Setting: In-hospital

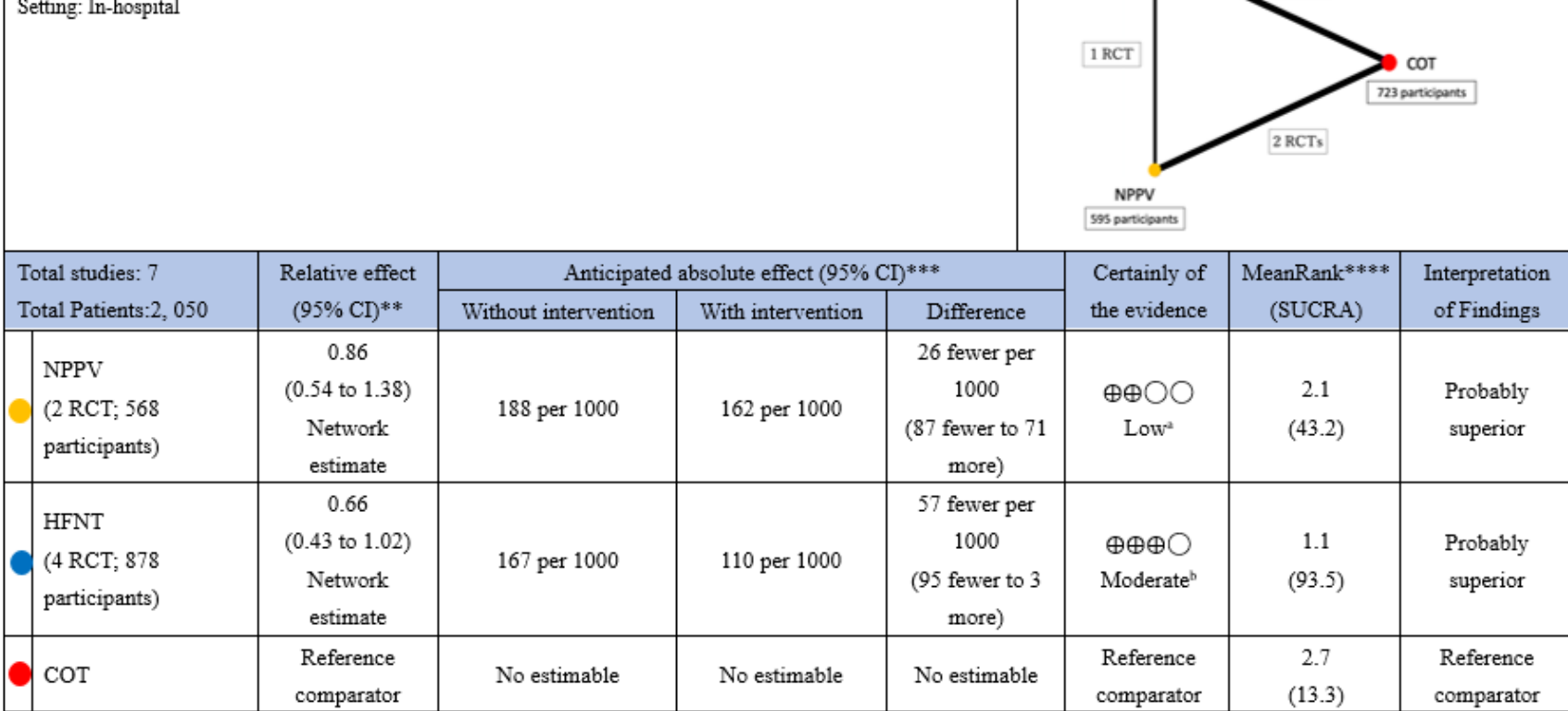

\begin{tabular}{|c|c|c|c|c|c|c|c|}
\hline $\begin{array}{l}\text { NPPV } \\
\text { (1 RCT; } 604 \\
\text { participants) }\end{array}$ & $\begin{array}{c}1.30 \\
(0.79 \text { to } 2.14) \\
\text { Network } \\
\text { estimate }\end{array}$ & 269 per 1000 & 350 per 1000 & $\begin{array}{c}81 \text { more per } \\
1000 \\
\text { (56 fewer to } 307 \\
\text { more) }\end{array}$ & $\begin{array}{c}\oplus \oplus \bigcirc \bigcirc \\
\text { Low }^{2}\end{array}$ & - & $\begin{array}{l}\text { Probably } \\
\text { equivalent }\end{array}$ \\
\hline HFNC & $\begin{array}{l}\text { Reference } \\
\text { comparator }\end{array}$ & No estimable & No estimable & No estimable & $\begin{array}{l}\text { Reference } \\
\text { comparator }\end{array}$ & - & $\begin{array}{l}\text { Reference } \\
\text { comparator }\end{array}$ \\
\hline
\end{tabular}

NMA, network meta-analysis: NPPV, non-invasive positive pressure ventilation; HFNC, high-flow nasal cannula; COT, conventional oxygen therapy; SOF, summary of findings:

SUCRA, surface under the cumulative ranking

NMA-SoF table definitions

${ }^{*}$ Lines represent direct comparisons

** Estimates are reported as risk ratio. CI: confidence interval.

${ }^{8 * 8}$ Anticipated absolute effect. Anticipated absolute effect compares two risks by calculating the difference between the risks of the intervention group with the risk of the control group.

${ }^{* * * 8}$ Rank for efficacy outcome are presented. Rank statistics is defined as the probabilities that a treatment out of $n$ treatments in a network meta-analysis is the best, the second, the third and so on until the least effective treatment.

GRADE Working Group grades of evidence (or certainly in the evidence)

High quality: We are very confident that the true effect lies close to that of the estimate of the effect.

Moderate quality: we are moderately confident in the effect estimate: The true effect is likely close to the estimate of the effect, but there is a possibility that it is substantially different Low quality: Our confidence in the effect estimate is limited: The true effect may be substantially different from the estimate of the effect.

Very low quality: We have very little confidence in the effect estimate: The true effect is likely to be substantially different from the estimate effect

Explanatory Footnotes

a) Confidence interval extends into clinically important effects in both directions.

b) Confidence interval extends into clinically important effects.

Figures 
A. Short-term mortality

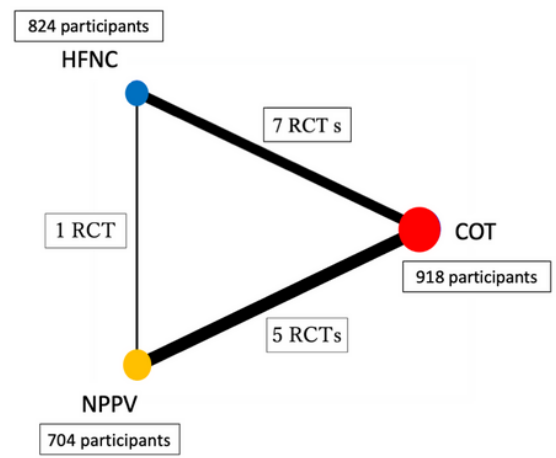

B. Reintubation

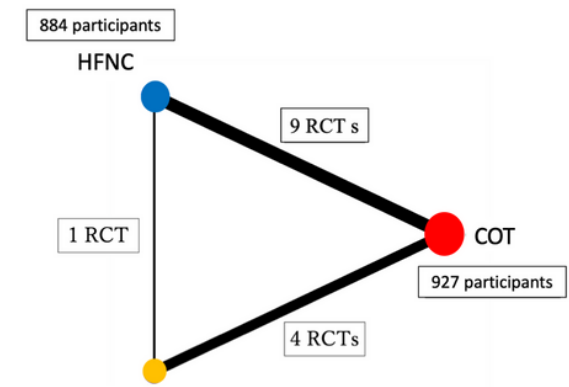

C. Post-extubation respiratory failure

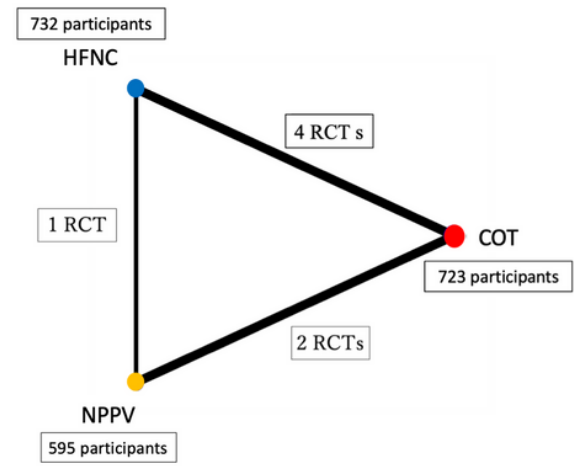

\section{Figure 1}

Network plots for the association of noninvasive oxygenation strategies with short-term mortality, reintubation, and post-extubation respiratory failure. A. Short-term mortality. B. Reintubation, C. Post-extubation respiratory failure. 
A. Short-term mortality

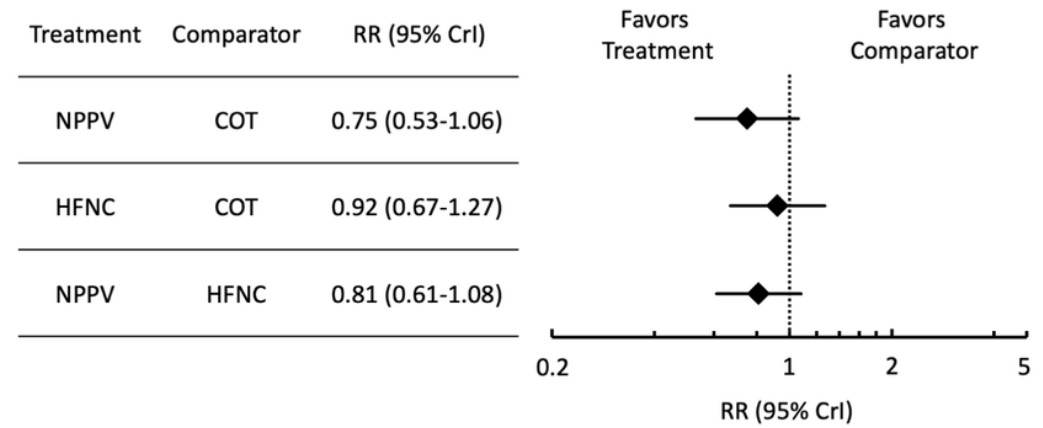

B. Reintubation

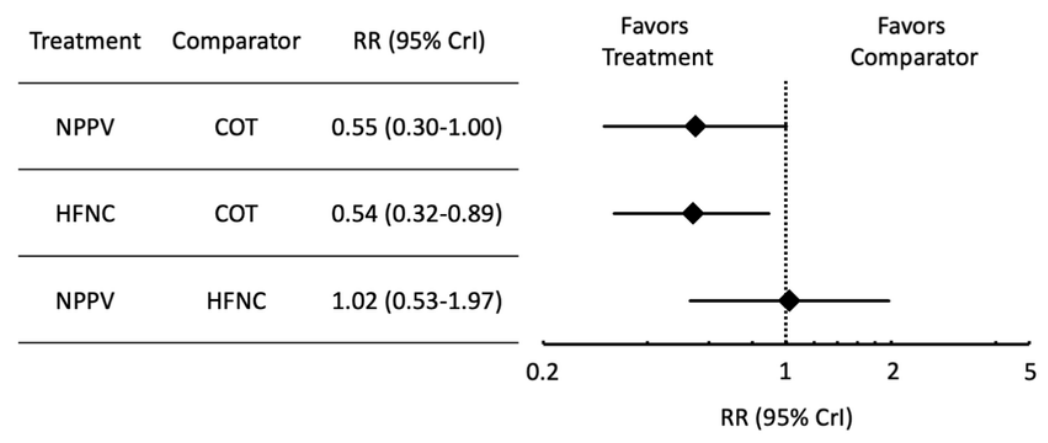

C. Post-extubation respiratory failure

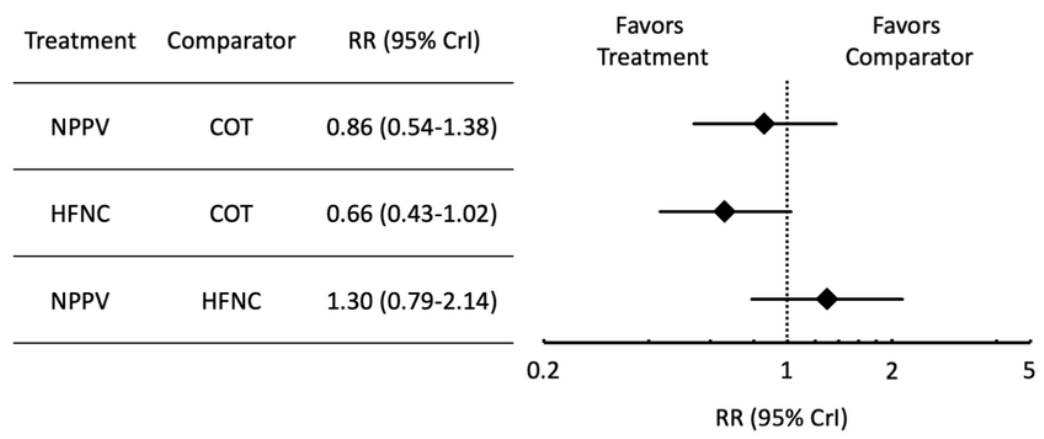

\section{Figure 2}

Forest plots of the network meta-analysis for the associations of noninvasive oxygenation strategies with short-term mortality, reintubation, and post-extubation respiratory failure. A. Short-term mortality. B. Reintubation. C. Post-extubation respiratory failure.

A

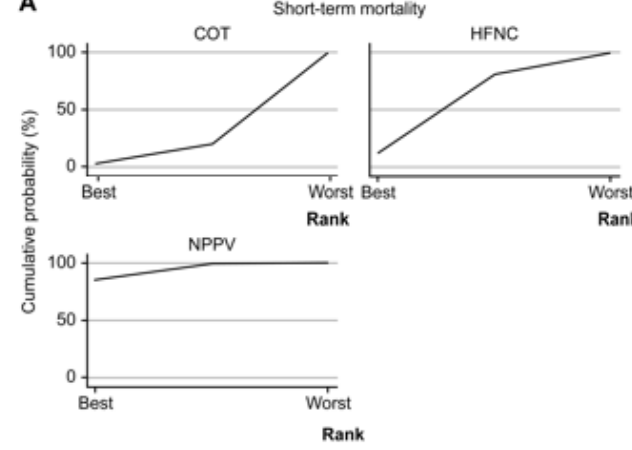

\begin{tabular}{cccc}
\hline Treatment & SUCRA & PrBEST & Mean Rank \\
\hline NPPV & 93.2 & 87.1 & 1.1 \\
HFNC & 36.7 & 7.0 & 2.3 \\
COT & 20.1 & 5.3 & 2.6 \\
\hline
\end{tabular}

B

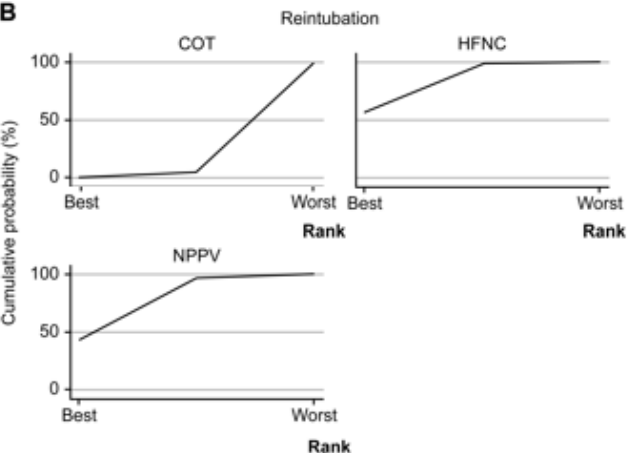

\begin{tabular}{cccc}
\hline Treatment & SUCRA & PrBEST & Mean Rank \\
\hline NPPV & 71.6 & 47.3 & 1.6 \\
HFNC & 75.8 & 52.5 & 1.5 \\
COT & 2.5 & 0.2 & 2.9 \\
\hline
\end{tabular}

c

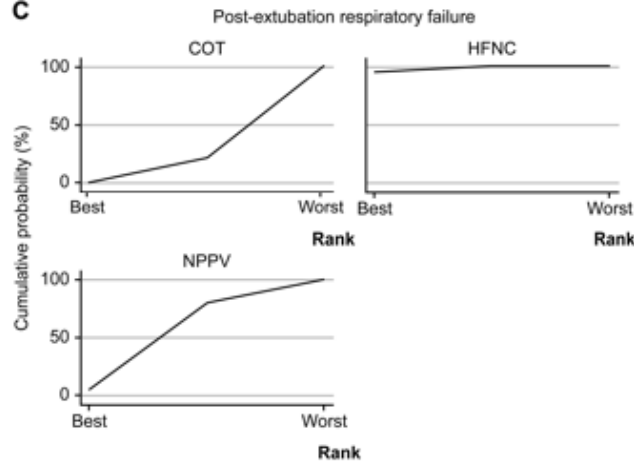

\begin{tabular}{cccc}
\hline Treatment & SUCRA & PrBEST & Mean Rank \\
\hline NPPV & 43.2 & 10.9 & 2.1 \\
HFNC & 93.5 & 87.8 & 1.1 \\
COT & 13.3 & 1.3 & 2.7 \\
\hline
\end{tabular}


Figure 3

Surface under the cumulative ranking of each noninvasive oxygen strategies for short-term mortality, reintubation, and post-extubated respiratory failure. A. Short-term mortality. B. Reintubation. C. Post-extubation respiratory failure

\section{Supplementary Files}

This is a list of supplementary files associated with this preprint. Click to download.

- OnlineCQ96JIC.docx 